\title{
The Application of Public Relations in Modern Enterprise Management
}

\author{
Chengran Zhang \\ Public Relation, University of westminster, London, HA1 3TP, United Kingdom
}

\begin{abstract}
With the development of global economy and society, public relations, as a new management discipline, is more and more applied to enterprise management. At the same time, the definition of public relations in the development process has always been different, each definition explains the characteristics of public relations from different aspects. Therefore, it is particularly important to discuss the role of public relations in enterprise management. Combined with the actual case analysis, public relations in enterprise management can not only build a good image for enterprises, can help enterprises deal with the crisis through difficulties, but also can coordinate the relationship between enterprises and the public.with the development and progress of modern enterprises, public relations is no longer an activity mode of external publicity, but an indispensable management mode in the process of continuous development of enterprises. The scientific management of public relations can not only create a successful brand for the enterprise, but also pave the way for the scientific management within the enterprise, and reasonably regulate the relationship between the enterprise and the outside society, as well as the relationship between the enterprise employees. This paper discusses the application of public relations in enterprise management.
\end{abstract}

Keywords: Public relations, Business management, Application.

\section{The Present Situation of Public Relations in Modern Enterprise Management}

Relational public relations public prosecutions have rushed to China's public relations market, joined forces with Chinese companies or established offices and business points, which has played a positive role in the specialization, professionalization and internationalization of China's public relations market [1]. Although China's public relations are developing rapidly, there are still many problems. The industry is growing The tide of world economic integration is impacting our new life. The vigorous development of global public relations has brought greater development opportunities and more severe challenges to China's public relations. In the past 20 years, public relations of / to / between mainland China have developed rapidly. China's contemporary public relations originated in hotels, restaurants and tourism. These effective public relations activities in the tourism hotel industry have played a great role in promoting the survival and development of enterprises. Therefore, public relations have also been valued and adopted by some large and medium-sized state-owned enterprises, and has shown considerable power in practice. At present, the localized public relations companies have made great progress. China's public relations market has initially taken shape and continues to maintain a good growth momentum. Intapidly and there is a gap between regions. Beijing, Shanghai and Guangzhou have always been the focus of China's public relations market. The regional gap makes the development of China's public relations industry unbalanced. With the continuous emergence of new companies and the intensification of talent flows / flowed, directors and account managers have become the two most scarce talents for the market. Modern public relations are a very young industry in China. Compared with international public relations giants, local public relations companies have obvious disadvantages.
Local public relations companies have made great progress of recent years. Compared with international public relations companies, they occupy the best time, place and people, but their disadvantages are also obvious: weak strength, low popularity and insufficient business experience. Many Chinese capitals public relations companies has / had weak foundation and low popularity, while the international public relations giants competing with them have extraordinary strength. In public bidding, international public relations companies mainly win by business experience, service quality and service resources, while local public relations companies rely too much on executive power.

\section{The Role of Public Relations in Modern Enterprise Management}

The role of public relations of / to / between enterprise management is very important. Enterprise public relations are a main part of the whole public relations and the most important field of public relations research. On the premise of abiding by socialist public morality and professional ethics, enterprise public relations refer to using certain communication methods to enhance the communication, understanding and cooperation between enterprises and the public, expand the influence of enterprises in the public, establish enterprise reputation, shape a good enterprise image, and create a harmonious social environment for the survival and development of enterprises, In order to obtain as much economic and social benefits as possible. It includes the following aspects: first, enterprise public relations is the relationship between enterprises and their related public. Second, public relations are a two-way communication activity between enterprises and the public. Third, enterprise public relations is a unique management function [2]. Fourth, enterprise public relations are restricted by social behavior norms. These four aspects are interrelated and interact, which plays an important role in the survival and development of enterprises. 


\subsection{Public Relations Promoting the Improvement of Labor Productivity.}

The key to the survival and development of enterprises is the development degree of labor productivity. The higher the labor productivity, the more the use value of production per unit times / timed. The level of labor productivity depends on various economic and technical factors, such as the proficiency of workers, whether the labor organization is reasonable, the combination and efficiency of production equipment, the status of labor objects and natural conditions. The important function of management is the coordination and reasonable combination of various elements of productivity, and public relations can create conditions for the development of productivity from the perspective of internal and external relations of enterprises. Therefore, a wise enterprise should handle public relations well.

\subsection{Public Relations Widely Collecting Information, Predict Trends and Ensure That Enterprises Can Hear and See for Business Management Activities}

Market economy is an exchange economy guided by consumer demand, dominated by enterprises, centered on the market and aimed at meeting the needs of others. Its operation formula is: consumer demand - design, production - market exchange - consumer demand. This is a continuous cycle process. From this process, we can see that whether the enterprise's economic activities are smooth and the level of economic interests depends on whether the enterprise can make correct decisions and promote the successful development of the enterprise. Mr. Tang Huanzhong, general manager of Shenzhen Xinguang dairy and beverage company, after tasting the benefits of public relations in practice, said with deep experience: " there is no doubt that information communication is the main feature of modern public relations. If enterprises want to develop, they have to rely on public relations to communicate more useful information.". public relations are closely combined with enterprise management strategies, The production and operation activities of enterprises can achieve great results.

\subsection{Public relations Establishing Reputation, Shape Image and Improve Popularity and Reputation for Enterprises}

Doing a good job of public relations can strengthen the connection between enterprises and the public, improve the competitiveness of enterprises, help enterprises promote business and promote product sales [3]. The core of the market is the relationship between supply and demand of commodities. With the significant transformation from China's seller's market to buyer's market, China's shortage economic phenomenon has changed, people's living standards have been continuously improved, and the requirements for commodities are becoming higher and higher. For consumers, when the general technical quality indicators are almost the same, the decision to buy the products or services of an enterprise mainly depends on the enterprise, that is, the image of the enterprise's products or services in their hearts. After people's needs are basically met, people gradually turn to higher-level pursuit and pursue psychological and spiritual satisfaction, which objectively requires enterprises to establish a good reputation and image and improve social popularity. The reform of economic system makes enterprises gradually become the main body of economic operation, and makes the contact between enterprises and the outside world unprecedented extensive and frequent. How to win the support of all sectors of society, shape a good corporate image and constantly expand market share is the key to the development of enterprises. Public relations aim to establish a corporate image, make consumers have a good impression on the enterprise and create a preference for the enterprise.

\subsection{Public Relations Can Straighten Out the Internal Relations of Enterprises and Enhance Cohesion}

Public relations can deal with the relationship between enterprises and employees, strengthen internal unity and enhance enterprise cohesion. The purpose of internal public relations is to strengthen internal unity and improve the quality of enterprises. This is not only the guarantee of enterprises to carry out effective external public relations, but also the basis of enterprise public relations. From the perspective of public relations, enterprise competitiveness is the external expression of enterprise cohesion. First of all, pay attention to internal communication, regard employees as the first object of communication, and timely and accurately spread important information about the enterprise and the overall situation of the enterprise to employees by using various media and enterprise magazines, briefings, newspapers, etc, so as to enhance employees ' sense of ownership and integrate employees with the enterprise in information sharing [4]. Secondly, the " glass house " internal public relations communication mode is advocated to continuously improve the transparency of the enterprise's daily operation and management and decision-making process. At the same time, it is also necessary to summarize and synthesize the employees ' emotions, opinions and suggestions, and feed them back to the enterprise leaders in time as the basis of decision-making, so that the leaders and the masses can communicate with each other, so as to achieve " letting the superior down " and " reaching the lower down ", and strive for the trust and help of the employees to the enterprise. Thirdly, pay attention to emotional investment and incentive to create a satisfactory family atmosphere.

\section{Ways of Effectively Using Public Relations in Modern Enterprise Management}

\subsection{Making Full Use of and Give Full Play to the Role of Daily Affairs Public Relations}

In the daily operation of the enterprise, we should consistently implement the objectives of public relations, strive to establish an image, strive for the public and expand influence. It specifically requires that in the whole link of daily operation and all channels, we should always pay attention to the image problem, and leave a good impression everywhere, so as to leave a good impression on the internal and external public. In order to win over the public and establish reputation, enterprise organizations should strictly control the purchase of raw materials, product production, sales and wholesale, so as to ensure quality, reasonable pricing and high-quality service. At the same time, care should be given to the labor protection, Living welfare, medical insurance and family problems of internal employees. 
The key point of this kind of work is that all the work of enterprise organization must be civilized, institutionalized and practical. We should establish the concept of civilized management ideologically. Even if there are contradictions with the public, we should properly deal with them in the spirit of being strict with ourselves and being lenient to others. Both the internal and external public should treat each other sincerely and do not do things that harm others and benefit themselves.

\subsection{Dissemination of Information}

Enterprises should use various media as tools to consciously disseminate relevant information about the public around a specific subject, such as introducing themselves to the public through press conferences, exhibitions, sponsorship, opening-up visits, banquets and celebrations, so as to create a favorable social public opinion environment. However, it must be not that the choice of media varies according to different public and economic conditions; The publicity subject and purpose should be clear; The facts or information publicized shall be objective and true; The arrangement and implementation of publicity work must be timely and rapid; Publicity methods should be appropriate.

\subsection{Dealing with Accidents}

In recent years, in the practice of public relations, crisis public relations has become the latest content of public relations and has been developed. Because the crisis is sudden, we need to respond immediately after the crisis to reduce the losses caused by the crisis. Whether before, during or after a crisis, it should constitute a logical plan. If an event happens, what to do and how to do it must be considered immediately. The public relations department shall make a comprehensive prediction and handling plan for possible crisis events in advance. 1. Prediction and analysis: how many crises are likely to occur, the nature and scale of various crises, the scope of the impact of the crisis and the organization's ability to deal with the crisis. 2. Develop contingency plans. Formulate corresponding emergency plans for various crises predicted and analyzed, arrange suitable personnel to deal with the problems in each link after the crisis, and let these personnel know what to do in the face of different crises in advance. The emergency plan shall be written and submitted to the upper management department for approval. 3. The emergency plan shall be introduced to employees in an easy to understand way. 4. Identify speakers, publish facts in a timely and appropriate manner, let people understand the situation and make rational analysis and judgment. 5. Train key employees. 6. Keep in touch with the press. 7. Comfort the victims and their families. 8. Establish contact with units that may ask for help, such as hospitals, fire departments, public security bureaus, etc.

\subsection{Taking the Initiative to Make News}

Public relations personnel can make some news in a planned and active way to attract the attention of the press and the public, so as to improve the popularity of the enterprise and establish a good image [5]. It can create news on the topics that the public is most concerned about in a period of time. When making news, we should consciously connect the organization with some authoritative figures and celebrities, pay attention to holding activities jointly with news agencies, and create some warm atmosphere in advance, so as to make the public psychologically prepared and achieve the effect of strengthening news making.

\section{Conclusion}

In the process of enterprise management, public relations plays a very important role. Its specific functions are as follows: first, public relations can strengthen the communication between enterprises and customers. By carrying out public relations, enterprises can understand the information fed back by customers, and adjust their business strategies in time according to the information fed back by customers, so as to improve customer satisfaction. Second, public relations guides enterprises to formulate correct development goals. The public relations department shall communicate with customers and media in time to understand the actual needs of the market, so that enterprises can formulate development goals according to the actual needs of the market. Third, public relations helps to improve the social popularity of enterprises and create a harmonious internal working environment. Public relations is to transmit the positive energy information of the enterprise to the public, and collect some negative energy information in time, and then correct it in time, which will help the enterprise establish a good social image. In addition, the implementation of public relations helps to create a harmonious internal working environment.

Under the tide of the development of socialist market economy, public relations are more and more applied to enterprise management. As a special management art, public relations can not only establish a good corporate image for enterprises in the public, but also play an important role in the improvement of internal management system, the construction of cultural atmosphere and sustainable development. However, the existing research on public relations theory and its management methods has different opinions, which has brought trouble to enterprise managers. By summarizing the existing research basis and current situation of the application of public relations and enterprise management, this paper expounds the development origin, content and characteristics of public relations and the application of public relations in enterprise management, analyzes the common problems and reasons of enterprise public relations, and puts forward that the implementation of enterprise public relations condenses the cultural atmosphere, constructs the enterprise public relations system and sets up public relations institutions, provide effective ways to ensure the organization of enterprise public relations, establish enterprise brand and improve the social reputation of enterprises, in order to provide constructive opinions and suggestions for the application of public relations in enterprise management.

\section{References}

[1] Excellence in public relations and communication management. Grunig, J.E. Lawrence Erlbaum Associates, Inc . 2019.

[2] Social media use, perceptions of decision-making power, and public relations roles $[\mathrm{J}]$. Marichris Diga,Tom Kelleher. Public Relations Review . 2019 (4).

[3] Institutionalizing public relations: A case study of Chinese government crisis communication on the 2008 Sichuan earthquake[J] . Ni Chen. Public Relations Review . 2018(3).

[4] The Social Media Release as a public relations tool: Intentions to use among B2B bloggers[J] . Peter Steyn,Esmail Salehi- 
Sangari,Leyland Pitt,Michael Parent,Pierre Berthon. Public Relations Review . 2019 (1).
[5] How Investor Relations (IR) Firms Can Boostthe Market Prospects of Small Companies. Morson G. http//www.niri.org/about/origins-ch1 . 2019. 